\title{
Kandungan Total Polifenol dan Aktivitas Antioksidan dari Ekstrak Metanol Akar Imperata cylindrica (L) Beauv. (Alang-alang)
}

\author{
Diah Dhianawaty, ${ }^{1}$ Ruslin ${ }^{2}$ \\ ${ }^{1}$ Departemen Biokimia dan Biomolekular Fakultas Kedokteran Universitas Padjadjaran Bandung. \\ ${ }^{2}$ Fakultas Farmasi Universitas Halu Oleo Kendari
}

\begin{abstract}
Abstrak
Hipertensi disebabkan oleh banyakfaktor, diantaranya aktivitas enzim konversiangiotensin, angiotensin-converting enzyme (ACE), dan reactive oxygen species (ROS). Ekstrak metanol akar Imperata cylindrica (alang-alang) terbukti mempunyai aktivitas antihipertensi. Studi menunjukkan berbagai terapi antioksidan dapat menurunkan tekanan darah. Senyawa polifenol dari tumbuh-tumbuhan mempunyai banyak manfaat, di antaranya sebagai antioksidan, oleh karena itu dilakukan studi ekperimental untuk mengukur kandungan polifenol total menggunakan metode spektrofotometri sinar tampak pereaksi Folin-Ciocalteu, dan uji aktivitas antioksidan dengan metode 1,1-difenil2-pikrilhidrazil (DPPH). Penelitian dilakukan periode Juli sampai Desember 2014. Hasilnya, ekstrak mempunyai

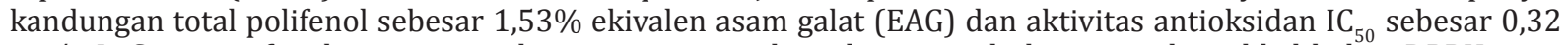
$\mathrm{mg} / \mathrm{mL}$. Senyawa fenol mempunyai kemampuan mendonorkan atom hidrogen pada radikal bebas DPPH yang menyebabkan DPPH tereduksi dan ditandai dengan perubahan warna DPPH dari ungu menjadi kuning. Dengan demikian, aktivitas antioksidan ekstrak metanol akar Imperata cylindrica didukung oleh senyawa polifenol. Simpulan, ekstrak mempunyai kandungan polifenol total 1,53\% (EAG) dan aktivitas antioksidan $\mathrm{IC}_{50} 0,32 \mathrm{mg} / \mathrm{mL}$. Senyawa polifenol mendukung aktivitas antioksidan ekstrak. [MKB. 2015;47(1):60-4]
\end{abstract}

Kata kunci: Aktivitas antioksidan, Imperata cylindrica, kandungan polifenol total

\section{Total Polyphenol Content and Antioxidant Activity of Methanol Extract of Imperata cylindrica (L) Beauv. (Alang-alang) Root}

\begin{abstract}
Hypertension is caused by many factors, including by the activity of angiotensin converting enzyme (ACE), reactive oxygen species (ROS). Methanol extract of Imperata cylindrica (alang-alang) root has been proven as having anti-hypertensive activities. Study shows various antioxidant therapies can decrease blood pressure. Polyphenol compounds of plants have many benefits, including as an antioxidant. Therefore, an experimental study was performed to measure the total polyphenol content using visible spectrophotometry method-FolinCiocalteu reagent as well as to test the antioxidant activity using 1,1-diphenyl-method 2-pikrilhidrazil (DPPH) from July to December 2014. The results showed that the extract had a total polyphenol content of $1.53 \%$ galad acid aquevalent (GAE) and antioxidant activity IC50 $0.32 \mathrm{mg} / \mathrm{mL}$. The polyphenol compounds have the ability to donate hydrogen atom to DPPH free radical, which leads to reduced DPPHmarked by the color change of DPPH from purple to yellow. Thus, antioxidant activity of methanol extract of Imperata cylindrica root was supported by the presence of polyphenol compounds. In conclusion, the extract has a total polyphenol content of $1.53 \%$ (GAE) and antioxidant activity IC50 0.32 of $0.32 \mathrm{mg} / \mathrm{mL}$. The presence of polyphenol compounds supports the antioxidant activity of the extract. [MKB. 2015;47(1):60-4]
\end{abstract}

Key words: Antioxidant activity, Imperata cylindrica, total polyphenol content

Korespondensi: Dr. Diah Dhianawaty, Dra., M.Si, Departemen Biokimia Biologimolekuler Fakultas Kedokteran Universitas Padjadjaran, Jalan Raya Bandung-Sumedang Km. 21, Jatinangor, mobile 08122366990, e-mail: dhianawaty@yahoo.co.id 


\section{Pendahuluan}

Dari pedoman berbasiskan bukti tahun 2014 untuk pengelolaan penyakit darah tinggi pada orang dewasa, the EighthJoint NationalCommittee (JNC 8), telah mentabulasikan beberapa obat antihipertensi di antaranya inhibitor angiotensinconverting enzyme atau ACE, pemblok reseptor angiotensin, -blocker, tiazid-tipe diuretika, dan lainnya. ${ }^{1}$ Kondisi penyakit hipertensi saat ini meningkat, hipertensi sering dikaitkan dengan kelainan metabolik seperti diabetes melitus dan dislipidemia. Baru-baru ini telah dihipotesiskan bahwa stres oksidatif memerankan kunci dalam patogenesis hipertensi. ${ }^{1,3}$ Sudah diteliti bahwa penurunan aktivitas enzim glutation peroksidase dan superoksida dismutase pada subjek yang baru didiagnosis hipertensi dan belum diobati, hasilnya berbanding terbalik dengan tekanan darah. Produksi kadar hidrogen peroksida dan hidroperoksida lipid lebih tinggi pada penderita hipertensi. ${ }^{2}$

Reactive oxygen species atau ROS berlebihan terbukti merupakan suatu senyawa yang dapat menyebabkan dan memperburuk hipertensi. ${ }^{3-5}$ Reactive oxygen species yang dihasilkan oleh berbagai sumber seluler, termasuk mitokondria, oksidase, xantin oksidase, nikotinamida adenina dinukleotida (NADPH), turunan dari endotelium oksida nitrat sintase (eNOS), sikloksigenase, dan juga lipoksigenase adalah superoksida $\left(\mathrm{O}_{2}\right) \cdot{ }^{3-5}$ Superoksida itu merupakan suatu molekul yang berumur pendek, kemudian dapat mengalami dismutasi secara enzimatik menjadi hidrogen peroksida. Superoksida itu dapat mengoksidasi protein dan lipid, atau dapat bereaksi dengan NO dari endotel menghasilkan spesies nitrogen reaktif peroksi nitrit. NO dan spesies reaktif nitrogen lainnya kemudian dapat mengoksidasi protein, lipid, dan kofaktor enzim yang penting untuk meningkatkan stres oksidatif. Hidrogen peroksida yang dihasilkan dismutasi enzimatik $\mathrm{O}_{2}$, selanjutnya akan dapat dikonversi ke radikal hidroksil yang sangat reaktif (via kimia Fenton) yang dapat merusak asam deoksiribo nukleat (DNA). ${ }^{3-4}$

Beberapa senyawa dari polifenol mempunyai aktivitas antihipertensi. Beberapa penelitian juga memperlihatkan bahwa flavonoid dan tanin yang umumnya terdapat dalam buah-buahan, sayursayuran, serta minuman mampu menghambat nicotinamida adenine dinucleotida phosphat (NADPH) oksidase melalui penghambatan ACE, peningkatan eNOS-spesifik, dan juga mengubah ekspresi siklooksigenase-2 (COX-2). ${ }^{2-8}$ Flavonoid dan tanin menghambat aktivitas ACE, yang penting dalam pengaturan tekanan darah arteri. Aktivitas senyawa fenol berasal dari jumlah gugus hidroksil pada cincin benzena. Penelitian docking menunjukkan bahwa asam fenolat dan flavonoid menghambat ACE melalui interaksi dengan ion zink dan interaksi ini distabilkan oleh interaksi lain dengan asam amino pada sisi aktif.7

Obat tradisional terutama yang berasal dari tumbuhan (herbal) sudah dimanfaatkan oleh masyarakat untuk memelihara, mencegah, dan menyembuhkan berbagai penyakit. Masyarakat di Sulawesi Tenggara telah memanfaatkan akar alang-alang (Imperata cylindrica) sebagai obat hipertensi. ${ }^{8}$ Ruslin dkk. ${ }^{9}$ sudah membuktikan ekstrak metanol akar alang-alang yang diberikan secara oral pada dosis 60 dan $90 \mathrm{mg} / \mathrm{kgBB}$ mempunyai khasiat antihipertensi terhadap tikus jantan galur Wistar. Penelitian yang lainnya menyatakan ekstrak etanol daun alang-alang pada dosis 160 and $320 \mathrm{mg} / \mathrm{mL}$ yang diberikan secara intravena memberikan efek pengurangan tekanan jantung hewan coba kucing dari 266 menjadi $180 \mathrm{mmHg}$ tetapi tidak mempunyai efek pada detak jantung. Dosis efektif terkecil persen $\mathrm{IC}_{50}$ adalah $0,013 \mathrm{mg} / \mathrm{mL}$. Ekstrak ini memperlihatkan sifat vasodilatasi antihipertensi yang mirip dengan mekanisme kerja adrenalin. Ekstrak ini dapat dimanfaatkan untuk mengelola hipertensi. ${ }^{10}$

Ekstrak metanol akar alang-alang mempunyai aktivitas menurunkan hipertensi dan penelitian lain membuktikan proses stres oksidatif dapat menjadi penyebab hipertensi. Demikian juga halnya dengan senyawa yang memiliki aktivitas sebagai zat antioksidan antara lain senyawa fenol. Telah dibuktikan senyawa itu memiliki aktivitas antihipertensi. Tujuan penelitian ini mengukur kandungan polifenol total menggunakan metode spektrofotometri sinar tampak - pereaksi FolinCiocalteu, dan uji aktivitas antioksidan dengan metode 1,1-difenil-2-pikrilhidrazil (DPPH).

\section{Metode}

Desain penelitian adalah studi eksperimental, yang dikerjakan dari bulan Juli sampai Desember 2014 di laboratorium Biokimia dan Biomolekular FK Unpad kampus Jatinangor. Bahan yang diteliti adalah ekstrak metanol akar Imperata cylindrica, yang ditanam di Kendari (Sulawesi Tenggara) dengan pereaksinya DPPH dan asam galat dari Sigma Aldrich. Pengukuran dilakukan dengan spektrofotometer Eppendorf Biospectrometer Basic AG 22331 Hamburg seri: 6135 BJ. Pada penentuan kadar total senyawa fenol digunakan 


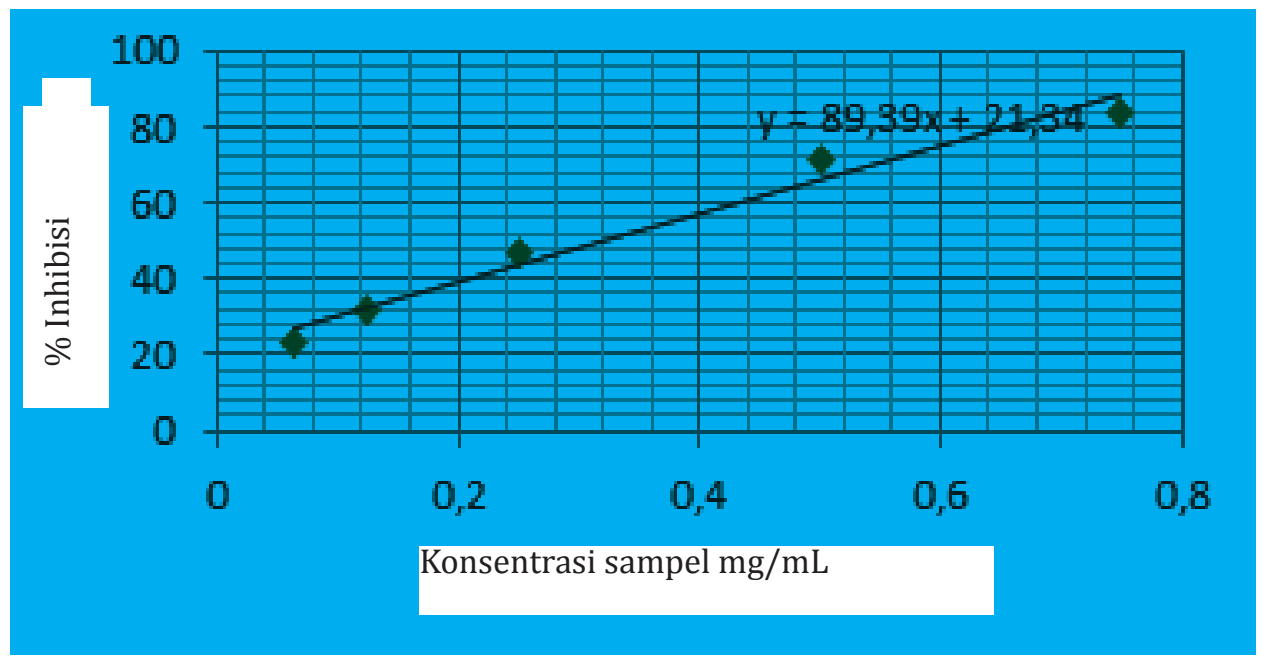

\section{Gambar Persen Inhibisi vs Konsentrasi dari Ektrak Metanol Akar Imperata Cylindrica}

asam galat sebagai standar acuan, dan hasilnya dinyatakan sebagai persen ekivalen asam galat (EAG). Untuk pengukuran perlu dibuat kurva baku asam galat yang dibuat dengan melarutkan asam galat baku dengan variasi konsentrasi 0,0 ; 0,$1 ; 0,2 ; 0,3 ; 0,4 ; 0,8 ; 1,6 \mathrm{mg} / \mathrm{mL}$. Dari kurva baku diperoleh persamaan regresi linier yang akan digunakan untuk menghitung kadar total senyawa fenol. Ekstrak sampel yang diteliti dilarutkan dalam metanol sampai konsentrasi $48,15 \mathrm{mg} / \mathrm{mL}$, sesudah itu diambil sebanyak 0,050 mL dan masukkan ke dalam tabung reaksi, kemudian ditambah dengan 2,5 mL pereaksi folin ciocalteau 10\%, $2 \mathrm{~mL} \mathrm{Na}$ karbonat (7,5\% b/v), dan diinkubasikan pada $37^{\circ} \mathrm{C}$ selama 30 menit. Selanjutnya, serapannya diukur pada panjang gelombang $750 \mathrm{~nm}$. Hasil serapan dihitung dengan memakai persamaan regresi linier dari kurva baku asam galat dan hasilnya dinyatakan sebagai persen ekivalen asam galat. ${ }^{11}$ Pada uji aktivitas antioksidan dengan pereaksi DPPH. ${ }^{12}$ Pertama kali disiapkan larutan stok DPPH dalam metanol dengan konsentrasi $\mathrm{M}$.

Tahap selanjutnya dipersiapkan larutan dari ekstrak metanol akar Imperata cylindrica dengan menimbang sebanyak $50 \mathrm{mg}$ dan dilarutkan dalam $50 \mathrm{~mL}$ metanol, kemudian dibuat dalam 5 variasi konsentrasi: 0,$750 ; 0,500 ; 0,250 ; 0,125$ dan 0,063 mg/50 mL. Selanjutnya sampel ekstrak masing-masing dicampur dengan $1 \mathrm{~mL}$ larutan stok DPPH, disimpan selama 30 menit. Setelah itu densitas optik (serapan) nya diukur dengan spektrofotometer pada panjang gelombang 517 nm, dan dihitung dengan memakai persamaan regresi linier dari kurva baku DPPH. Hasilnya adalah persentase konsentrasi penghambatan, yang dihitung persamaan $\% \mathrm{IC}_{50}=[$ (serapan baku - serapan sampel)/serapan baku]×100\%.

\section{Hasil}

Dari kurva baku asam galat diperoleh persamaan regresi liner yaitu $y=1,0055 x-0,0009$, kemudian persamaan ini dipergunakan untuk menghitung kadar total polifenol dalam ekstrak, dengan memasukkan serapan sampel ekstrak yang terbaca pada alat spektrofotometer sebagai nilai $\mathrm{y}$.

Dari perhitungan tersebut diperoleh nilai $\mathrm{x}$ yaitu konsentrasi polifenol dalam ekstrak 0,71; 0,71 ; dan $0,78 \mathrm{mg} / \mathrm{mL}$. Selanjutnya konsentrasi yang diperoleh diubah menjadi kadar yang hasilnya dinyatakan dalam satuan persen yaitu 1,$48 ; 1,47$; dan 1,63\%. Akhirnya diperoleh kadar polifenol total rata-rata dalam ekstrak metanol akar alang-alang = 1,53\% (EAG).

\section{Tabel 1 Kurva Baku Asam Galat}

\begin{tabular}{cc}
\hline $\begin{array}{c}\text { Konsentrasi Sampel } \\
\text { (mg/mL) }\end{array}$ & Serapan \\
\hline 0,0 & 0,000 \\
0,1 & 0,076 \\
0,2 & 0,229 \\
0,4 & 0,398 \\
0,8 & 0,801 \\
1,6 & 1,608 \\
\hline
\end{tabular}


Diah: Kandungan Total Polifenol dan Aktivitas Antioksidan dari Ekstrak Metanol Akar Imperata cylindrica (L) Beauv.

Tabel 2 Kadar Total Polifenol dari Ektrak Metanol Imperata Cylindrica

\begin{tabular}{ccccc}
\hline $\begin{array}{c}\text { Konsentrasi Sampel } \\
(\mathbf{m g} / \mathbf{m L})\end{array}$ & Serapan & $\begin{array}{c}\text { Konsentrasi Hasil } \\
\text { Pengukuran } \\
\text { (mg/mL) }\end{array}$ & $\begin{array}{c}\text { Kadar Polifenol } \\
\text { (\%) }\end{array}$ & $\begin{array}{c}\text { Kadar Polifenol } \\
\text { Rata-Rata } \\
\text { (\%) }\end{array}$ \\
\hline 48,15 & 0,714 & 0,71 & 1,48 & \\
48,15 & 0,711 & 0,71 & 1,47 & 1,53 \\
48,15 & 0,788 & 0,78 & 1,63 & \\
\hline
\end{tabular}

Aktivitas antioksidan dihitung dari aktivitas inhibisi ekstrak pada pereaksi DPPH yang juga berperan sebagai suatu radikal bebas. Dari hasil pengukuran diperoleh persamaan regresi linier $y=89,39 x+21,34$, dimana y adalah \% inhibisi dan $\mathrm{x}$ adalah $\mathrm{IC}_{50}$ yaitu konsentrasi dari antioksidan yang dapat meredam atau menghambat $50 \%$ radikal bebas. Dengan menggunakan rumus regresi tersebut diperoleh $\mathrm{IC}_{50}$ ekstrak metanol akar alang-alang=0,32 $\mathrm{mg} / \mathrm{mL}$.

\section{Pembahasan}

Ekstrak metanol akar alang-alang mengandung senyawa fenol, diperoleh kadar polifenol dalam ekstrak 1,48\%. Senyawa fenol merupakan suatu senyawa yang mengandung gugus hidroksil $(-\mathrm{OH})$ yang terikat langsung pada gugus cincin hidrokarbon aromatik. Klasifikasi senyawa fenol yang terkandung dalam tumbuhan yaitu fenol sederhana, benzoquinone, asam fenolat, asetofenon, naftokuinon, xanton, bioflavonoid kumarin, stilben, turunan tirosin, asam hidroksi sinamat, flavonoid, lignan, dan tanin..$^{13}$ Senyawa fenol alami yang bersifat antioksidan dapat diklasifikasikan dalam 2 (dua) kelompok, yaitu kelompok lipofilik dan hidrofilik (di antaranya senyawa fenol). ${ }^{13,14}$ Aktivitas antioksidan dari senyawa fenol terbentuk karena kemampuan senyawa fenol membentuk ion fenoksida yang dapat memberikan satu elektronnya kepada radikal bebas. Gambaran pada umumnya yaitu, antioksidan senyawa fenol ( $\mathrm{PhH})$ dapat bereaksi dengan radikal bebas (ROO•) membentuk $\mathrm{ROOH}$ dan sebuah senyawa fenol radikal $(\mathrm{Ph} \bullet$ ) yang relatif tidak reaktif. Selanjutnya, senyawa fenol radikal (Ph•) dapat bereaksi kembali dengan radikal bebas (ROO•) membentuk senyawa yang bersifat tidak radikal. ${ }^{13,14}$ DPPH adalah senyawa radikal bebas yang mampu bereaksi dengan senyawa yang dapat mendonorkan atom hidrogen. Terdapat senyawa antioksidan (polifenol/PhH) dalam ektrak akar alang-alang yang medonorkan atom hidrogen pada DPPH telah menyebabkan DPPH yang ditandai dengan pengurangan intensitas warna ungu

Pengurangan konsentrasi radikal bebas DPPH karena tereduksi ditandai dengan pengurangan intensitas warna ungu yang dapat diukur dengan alat spektrofotometer pada panjang gelombang $517 \mathrm{~nm}$. Dari hasil pengukuran metode DPPH, ekstrak metanol akar alang-alang mempunyai nilai $\mathrm{IC}_{50}=0,32 \mathrm{mg} / \mathrm{mL}$, artinya ekstrak metanol akar alang-alang mampu mengoksidasi radikal bebas DPPH, atau dapat dinyatakan mempunyai aktivitas sebagai antioksidan.

Sebagai simpulan penelitian, kadar polifenol total dalam ekstrak metanol akar alang-alang yaitu sebesar 1,53\% (EAG), kandungan senyawa polifenol sebagai donor atom hidrogen kepada DPPH yang mendukung aktivitas antioksidan

Tabel 3 Persentase Inhibisi Ekstrak Metanol Akar Imperata Cylindrica

\begin{tabular}{cccccc}
\hline No & $\begin{array}{c}\text { Konsentrasi } \\
(\mathbf{m g} / \mathbf{m L})\end{array}$ & $\mathbf{1}$ & $\mathbf{2}$ & Rata-rata & \multirow{2}{*}{ \% Inhibisi } \\
\cline { 3 - 5 } & 0,750 & 0,182 & 0,187 & 0,185 & 83,88 \\
1 & 0,500 & 0,316 & 0,331 & 0,324 & 71,77 \\
2 & 0,250 & 0,610 & 0,599 & 0,605 & 47,30 \\
3 & 0,125 & 0,791 & 0,785 & 0,788 & 31,35 \\
4 & 0,063 & 0,874 & 0,886 & 0,880 & 23,34 \\
5 & Baku pembanding & 1,145 & 1,150 & 1,148 & \\
\hline
\end{tabular}


esktrak dengan nilai $\mathrm{IC}_{50}=0,32 \mathrm{mg} / \mathrm{mL}$. Dengan demikian, aktivitas antioksidan yang dikandung oleh ekstrak metanol akar alang-alang berperan sebagai antihipertensi.

\section{Daftar pustaka}

1. James PA, Oparil S, Carter BL, Cushman WC, Himmelfarb CD, Handler J, dkk. 2014 Evidence-based guideline for the management of high blood pressure in adults. report from the panel members appointed to the eighth joint national committee (JNC 8). JAMA. 2014;311(5):507-20.

2. Baradaran A, Nasri H, Kopaei RM. Oxidative stress and hypertension: possibility of hypertension therapy with antioxidants. J Res Med Sci. 2014;19(4):358-367.

3. Sulastri D, Liputo NI. Konsumsi antioksidan dan ekspresi gen eNOS3 alel-786T $>$ C pada penderita hipertensi etnik Minangkabau. MKB. 2011;43(1):1-9.

4. Kizhakekuttu TJ, Widlansky ME. Natural antioxidants and hypertension: promise and challenges. Cardiovas Ther. 2010;28(4): e20-32.

5. Beg M, Sharma V, Akhtar N, Gupta A, Jasim M. Role of antioxidants in hypertension. J Indian Acad Clin Med. 2011;12(2):122-7.

6. Sharifi N, Souri E, Ziai SA, Amin G, Amanlou $M$. Discovery of new angiotensin converting enzyme (ACE) inhibitors from medicinal plants to treat hypertension using an in vitro assay. DARU J Pharm Sci. 2013;21:74-81

7. Guerrero L, Castillo J, Quiñones M, Vallvé SG, Arola L, Pujadas G, dkk. Inhibition of angiotensin-converting enzyme activity by flavonoids structure-activity relationship studies. PLOS One. 2012;(11):e49493.

8. Mensah MEE, Komlaga G, Terlabi EO. Antiypertensive action of ethanolic extract of Imperata cylindrica leaves in animal models. L Med Plants Resch. 2010;4(14):1486-91.

9. Dalimarta S., Atlas of Indonesian medicinal plants: Imperata cylindrica [L.] Beauv. No.4, Depok: Puspa Swara; 2006.

10. Ruslin, Asmawi MZ, Rianse U, Sahidin, Dhianawaty D, Soemardji AA, dkk. Antihypertensive activity of alang-alang (Imperata cylindrica) (L) Beauv. root methanolic extract on male Wistar rat. Int J Res Pharm Sci. 2013;4(4):537-42.

11. Shukor NA, Camp JV, Gonzales GB, Staljanssens D, Struijs K, Zotti MJ, dkk. Angiotensin-converting enzyme inhibitory effects by plant phenolic compounds: a study of structure activity relationships. J Agric Food Chem. 2013; 9:50-8.

12. Abe LT, Lajolo FM, Genovese MI. Comparison of phenol content and antioxidant capacity of nuts. Food Sci Technol. 2010;30 (Supp 1): 254-9.

13. Dhianawaty D, Panigoro R. Antioxidant activity of the waste water of boiled Zea mays (swett corn) on the cob. Int J Res Pharm Sci. 2013;4(2):266-9.

14. Saxena M, Saxena J, Nema R, Singh D, Gupta A. Phytochemistry of medicinal plants. J Pharmacog Phytochem. 2013;1(6):168-82.

15. Imperato F, Maestri DM, Nepote V, Lamarque AL, Zygadlo JA, penyunting. Phytochemistry: advances in research. Trivandrum: Research Signpost; 2006. 